\title{
Language Errors on Turn Taking “The Space Between Us” Movie: Overviewed within Translation Studies
}

\author{
Mochamad Nuruz Zaman \\ Department of Linguistics, Sebelas Maret University, Indonesia \\ Email: azzam.nuruzzaman93@student.uns.ac.id
}

http://dx.doi.org/10.18415/ijmmu.v5i2.307

\begin{abstract}
Either society or education areas teaches to have good communication for building interpersonal skills up. Everyone has the capacity to understand something new, either well comprehension or worst understanding. Worst understanding makes language errors when interactions are done by someone in the first meeting and they do not know before it because of distance area. "The Space between Us" movie delivers the love-adventure story. They are so many missing conversations. As the moviegoer must be focused on subtitle in order to enjoy well the movie. Indonesia subtitle and English conversation on the movie still have overlapping understanding in translation. Translations hereby consist of the source language (English conversation) and target language (Indonesia subtitle). These research gap above is formulated in research question by how language errors happened in that movie and their effects on translation quality which is deepest analyzed by translation studies through pragmatics approach. The research goal is to expand language errors and their translation qualities. The research is studied by embedded research in qualitative design. The research locations consist of setting, participant, and event as focused determined boundary. Sources of data are "The Space between Us" movie and informant (translation quality rater). The sampling is criterion-based sampling. Data collection techniques use content analysis. Data validation applies data source and method triangulation. Data analysis delivers domain, taxonomy, componential, and cultural theme analysis. Data findings on the language errors happened in the movie are referential, register, society, textual, receptive, expressive, analogical, and local. Data discussions on their effects on translation quality are concentrated by translation techniques on their data findings, they are a description, amplification, established equivalence, transposition, and adaptation
\end{abstract}

Keywords: Speech acts; Language errors; "The Space between Us" movie; Translation techniques; Translation quality

\section{Introduction}

We have just known each other, then I great you how do you do? Then you reply politely, how do you do? Then, when I great you with the same expression and reply "I'm fine"! It is questionable. It indicates that the hearer does the misunderstanding in turn taking the conversation. It also happened in the movie. Either society or education areas teaches to have good communication for building interpersonal 
skills up. Everyone has the capacity to understand something new, either well comprehension or worst understanding. Worst understanding makes language errors when interactions are done by someone in the first meeting and they do not know before it because of distance area. "The Space between Us" movie delivers the love-adventure story. They are so many missing conversations. As the moviegoer must be focused on subtitle in order to enjoy well the movie. Indonesia subtitle and English conversation on the movie still have overlapping understanding in translation. Translations hereby consist of the source language (English conversation) and target language (Indonesia subtitle). Here, language mistake found in the "The Space between Us" movie Gardner Elliot, the first human born on Mars, begins an online friendship with Tulsa, a teen in Colorado. On his maiden voyage to Earth, the 16-year-old finally gets to experience all the joys and wonders of a world he could only read about. Problems arise when scientists discover that Gardner's organs can't withstand the atmosphere. United with Tulsa and on the run, the interplanetary visitor races against time to unravel the mysteries of how he came to be, and where he belongs in the universe.

Based on the research gap above, researcher applies a research question to state the problem that how language error on turn taking happened in "The Space between Us" movie which overviewed within translation studies. The study has a goal to develop two findings, they are pragmatic aspects (language error and turn taking) and translation study for measuring the pragmatics aspects' affect toward their translation quality. The theoretical significance of the study is able to combine three studies (language error, turn taking, and translation quality) in the one object, namely movie that still in 2017. The practical significance is moviegoers can know the errors in the turn taking part analyzed, then they can understand the implicit meaning of Indonesia subtitle, because the movie delivers two areas, Mars and Earth.

There are important parts of the fundamental of the literature review of this analysis. They are pragmatics and translation. Pragmatics (Thomas., 1995) is meaning in use or meaning in a context dealing with speaker meaning and utterance interpretation that represent the intentions and the goals of speaker or hearer. Speaker meaning and utterance interpretation basically got from speech act, the term to the dialogue between two persons or more that consist of speaker and hearer. Yule (1996: 46) states that actions performed as utterances are called speech act", and Griffiths (2006: 148) says the basic units of linguistics interaction such as give the warning to greet, apply for, tell what, confirm an appointment (the acts not the label) are called speech acts". That reference delivers if a speaker always has an objective to the hearer to make the interaction. The utterance, by the result of conversation as well make the language error either speaker or hearer intention. Language error happened when the interaction does not balance because of unclear explanation or ambiguity statement (Markhamah., et al, 2010: 58). In translations, the language error needs more clearness for making the translation results accurate, acceptable, and readable.

One of the most prominent definitions of translation is stated by Newmark (1988: 5) who defines translation as "rendering the meaning of a text into another language in the way that the author intended the text". This definition stresses on rendering the meaning of the source language text into the target language text as what is intended by the author. Hatim and Munday (2004: 6) state translation as "the process of transferring a written text from the source language (SL) to target language (TL)". Here, they do not explicitly express that an object being transferred is meaning or message. They focus on translation as a process. Nida and Taber (1982: 12) define that "translating consists in reproducing in the receptor language the closest natural equivalent of the source language message". This definition is comprehensive than the previous. They explicitly state that translation is absolutely related to the problems of languages, meaning, and equivalence. From the definitions mentioned above, it is found that translation is a process which is intended to find meaning equivalence in the target text. Rochayah Machali (2001) and Mona Baker (1992) highline the term meaning equivalence because it is the meaning which is transferred in the target language. In this case, translators are faced with text as a unit of meaning in the form of the set of words or sentences. This means that language which is used is unit of meaning. 
Molina and Albir (2002: 509-511) classify translation techniques based on the following criteria such as, to isolate the concept of technique from other related notions (translation strategy, method and error), to include only procedures that are characteristic of the translation of texts and not those related to the comparison of languages, to maintain the notion that translation techniques are functional. Our definitions do not evaluate whether a technique is appropriate or correct, as this always depends on its situation in text and context and the translation method that has been chosen, in relation to the terminology, to maintain the most commonly used terms, and to formulate new techniques to explain mechanisms that have not yet been described. They classify translation techniques into 18. They are the adaptation, amplification, borrowing, calque, compensation, description, discursive creation, established equivalence, generalization, linguistics amplification, linguistics compression, literal, modulation, particularization, reduction, substitution, transposition, and variation.

\section{Methodology}

The research design is descriptive qualitative in form of embedded research namely translations and the context of them such as techniques and qualities. Lincoln and Guba (1985) via Santosa (2014: 47) defines research location as focus determined boundary, it literally means "research limitation based on focus or object". Spradley (1980) via Santosa (2014: 48) states that research location must have main elements, they are setting, participant, and event. The setting is "The Space Between us" movie directed by Peter Chelsom and Indonesia subtitle, the participant is the actor and actress dealing with the film, and the event is traveling of the boy to Earth. Sources of data are "The Space between Us" movie and informant (translation quality rater). The sampling is criterion-based sampling.

Data collection technique is documentary (bibliography study) that applied in content analysis, Yin (via Sutopo., 2002: 69) states the techniques of studying document is a way to find the findings out dealing with research question and goal. The technique as follows: comprehending the film context, integrating with the subtitle, finding out the data, speech act dealing with language errors, analyzing the subtitle that contains data by applying translation techniques, and analyzing those data and their effects to translation quality by using accuracy and acceptability translation indicator. The documentary study is also applied in questioner as a list of question that has a goal to collect the data both in spoken and written form (Sutopo., 2002: 70). It is given to translation quality rater as rater to measure accuracy and acceptability level. The table following indicates the translation quality instrument of the study.

Table 1 Scale and information of accuracy instrument

\begin{tabular}{|c|c|c|}
\hline $\begin{array}{c}\text { Translation } \\
\text { Category }\end{array}$ & Score & Qualitative Parameters \\
\hline Accurate & 3 & $\begin{array}{l}\text { The meaning of a word, technical term, phrase, clause, sentence or } \\
\text { source language text is accurately transferred into the target } \\
\text { language: there is absolutely no distortion of meaning }\end{array}$ \\
\hline Less Accurate & 2 & $\begin{array}{l}\text { The vast majority of the words, technical terms, phrases, clauses, } \\
\text { sentences or source language texts have been accurately } \\
\text { transitioned into the target language. But there is still a distortion } \\
\text { of meanings or double meaning translations (taxa) or there is a } \\
\text { meaning omitted, disturbing the integrity of the message }\end{array}$ \\
\hline Inaccurate & 1 & $\begin{array}{l}\text { The meaning of a word, technical term, phrase, clause, sentence or } \\
\text { source language text is inaccurately transferred into the target } \\
\text { language or deleted }\end{array}$ \\
\hline
\end{tabular}


Table 2 Scale and information of acceptability instrument

\begin{tabular}{lll}
$\begin{array}{c}\text { Translation } \\
\text { Category }\end{array}$ & Score & \multicolumn{1}{c}{ Qualitative Parameters } \\
\hline Acceptable & 3 & $\begin{array}{l}\text { Translation is natural: the technical terms used are commonly used } \\
\text { and familiar to the reader: the phrases, clauses, and sentences used } \\
\text { are in conformity with the Indonesian rules }\end{array}$ \\
Less Acceptable & 2 & $\begin{array}{l}\text { Generally, the translation has already been natural: but there is little } \\
\text { problem with the use of technical terms or a slight grammatical error } \\
\text { Translation is not natural or feels like the translation work: technical } \\
\text { terms used are not commonly used and are not familiar to the reader: } \\
\text { the phrases, clauses, and sentences used do not conform to the } \\
\text { Indonesian }\end{array}$ \\
\hline
\end{tabular}

Nababan., et.al (2012: 50-51)

Spradley (via Santosa., 2014: 66) states that data analysis technique divided into four stages. They are the domain, taxonomy, componential, and cultural theme analysis. The research applies pragmatics approach, Santosa (2014: 68) states that pragmatics consists of situational context diversity, it can be divided into distance or power. Here, focused on the subtitle, in turn, taking that experiences the language errors (referential, register, society, textual, receptive, expressive, analogical, transfer, and local). Each kind of language errors overviewed within translation techniques (established equivalent, transposition, modulation, and reduction). 
Table 3 Domain and taxonomy category analysis of language errors: overviewed within translation studies

\begin{tabular}{|c|c|c|c|}
\hline Domain Category & Language Errors & Translation Technique & Note \\
\hline \multirow{40}{*}{$\begin{array}{l}\text { Subtitle in Turn } \\
\text { Taking } \\
\text { (STT) }\end{array}$} & \multirow{5}{*}{$\begin{array}{l}\text { Referential } \\
\text { (RF) }\end{array}$} & Description (DC) & $\sqrt{ }$ \\
\hline & & Amplification (AP) & - \\
\hline & & Establish Equivalent (EE) & - \\
\hline & & Transposition (TP) & - \\
\hline & & Adaptation (AT) & - \\
\hline & \multirow{5}{*}{$\begin{array}{l}\text { Register } \\
\text { (RG) }\end{array}$} & Description (DC) & - \\
\hline & & Amplification (AP) & $\sqrt{ }$ \\
\hline & & Establish Equivalent (EE) & - \\
\hline & & Transposition (TP) & - \\
\hline & & Adaptation (AT) & - \\
\hline & \multirow{5}{*}{$\begin{array}{c}\text { Society } \\
\text { (SC) }\end{array}$} & Description (DC) & - \\
\hline & & Amplification (AP) & - \\
\hline & & Establish Equivalent (EE) & $\sqrt{ }$ \\
\hline & & Transposition (TP) & - \\
\hline & & Adaptation (AT) & - \\
\hline & \multirow{5}{*}{$\begin{array}{c}\text { Textual } \\
\text { (TT) }\end{array}$} & Description (DC) & - \\
\hline & & Amplification (AP) & - \\
\hline & & Establish Equivalent (EE) & - \\
\hline & & Transposition (TP) & $\sqrt{ }$ \\
\hline & & Adaptation (AT) & - \\
\hline & \multirow{5}{*}{$\begin{array}{c}\text { Receptive } \\
\text { (RC) }\end{array}$} & Description (DC) & - \\
\hline & & Amplification (AP) & - \\
\hline & & Establish Equivalent (EE) & $\sqrt{ }$ \\
\hline & & Transposition (TP) & - \\
\hline & & Adaptation (AT) & - \\
\hline & \multirow{5}{*}{$\begin{array}{l}\text { Expressive } \\
\text { (EX) }\end{array}$} & Description (DC) & - \\
\hline & & Amplification (AP) & - \\
\hline & & Establish Equivalent (EE) & - \\
\hline & & Transposition (TP) & $\sqrt{ }$ \\
\hline & & Adaptation (AT) & - \\
\hline & \multirow{5}{*}{$\begin{array}{l}\text { Analogical } \\
\text { (AL) }\end{array}$} & Description (DC) & $\sqrt{ }$ \\
\hline & & Amplification (AP) & - \\
\hline & & Establish Equivalent (EE) & - \\
\hline & & Transposition (TP) & - \\
\hline & & Adaptation (AT) & - \\
\hline & \multirow{5}{*}{$\begin{array}{l}\text { Local } \\
\text { (LC) }\end{array}$} & Description (DC) & - \\
\hline & & Amplification (AP) & - \\
\hline & & Establish Equivalent (EE) & - \\
\hline & & Transposition (TP) & - \\
\hline & & Adaptation (AT) & $\sqrt{ }$ \\
\hline
\end{tabular}


Table 4 Componential category analysis of language errors: overviewed within translation studies

\begin{tabular}{|c|c|c|c|c|c|c|}
\hline \multirow{3}{*}{ Data Coding of Domain and Taxonomy Category } & \multicolumn{6}{|c|}{ Translation Quality } \\
\hline & \multicolumn{3}{|c|}{ Accuracy } & \multicolumn{3}{|c|}{ Acceptability } \\
\hline & 3 & 2 & 1 & 3 & 2 & 1 \\
\hline 1/STT/RF/DC & - & $\sqrt{ }$ & - & - & $\sqrt{ }$ & - \\
\hline 2/STT/RG/AP & - & $\sqrt{ }$ & - & - & - & $\sqrt{ }$ \\
\hline 3/STT/SC/EE & $\sqrt{ }$ & - & - & - & $\sqrt{ }$ & - \\
\hline 4/STT/TT/TP & - & $\sqrt{ }$ & - & $\sqrt{ }$ & - & - \\
\hline 5/STT/RC/EE & - & $\sqrt{ }$ & - & - & $\sqrt{ }$ & - \\
\hline 6/EX/EX/TP & $\sqrt{ }$ & - & - & - & $\sqrt{ }$ & - \\
\hline 7/STT/LC/AT & - & $\sqrt{ }$ & - & - & $\sqrt{ }$ & - \\
\hline 8/STT/LC/AT & $\sqrt{ }$ & - & - & - & $\sqrt{ }$ & - \\
\hline 9/STT/LC/AT & - & $\sqrt{ }$ & - & - & $\sqrt{ }$ & - \\
\hline
\end{tabular}

Table 5 Cultural theme category analysis of language errors: overviewed within translation studies

Data Coding of Componential Analysis

Discussion

\begin{tabular}{ll} 
1/STT/RF/DC/AR-2/AP-2 & The finding is less accurate and less acceptable \\
2/STT/RG/AP/AR-2/AP-1 & The finding is less accurate and not acceptable \\
3/STT/SC/EE/AR-3/AP-2 & The finding is very accurate and less acceptable \\
4/STT/TT/TP/AR-2/AP-3 & The finding is less accurate and very acceptable \\
5/STT/RC/EE/AR-2/AP-2 & The finding is less accurate and less acceptable \\
6/EX/EX/TP/AR-3/AP-2 & The finding is very accurate and less acceptable \\
7/STT/AL/AT/AR-2/AP-2 & The finding is less accurate and less acceptable \\
8/STT/LC/AT/AR-3/AP-2 & The finding is very accurate and less acceptable \\
9/STT/LC/AT/AR-2/AP-2 & The finding is less accurate and less acceptable \\
\hline
\end{tabular}

\section{Results and Discussion}

Some findings in this research are categorized into eight studies. They are a language errors, in turn taking (referential, register, society, textual, receptive, expressive, analogical, and local) that happened in "The Space between Us" movie. Pateda (1989: 39), in his book entitled Analisis Kesalahan defines as following and the researcher delineates this into description why they have happened there.

\section{Referential Error}

Corder (via Pateda., 1989: 39) states “...where the speaker uses a term with the intention of referring to someone feature of the world to which it is conventionally applicable". Referential error deals with the realization of think, process, or phenomena that is unappropriated with the speaker's intention. To avoid this wrong intention, the speaker should deliver it clearly and unambiguity. When the speaker says school desk, it will be different realization when he or she says the only desk, because the desk is a general thing. 
Hereby, the referential error is shown in the duration of 26:14-26:36

Source Text

Tulsa $\quad:$ Oh, right, you can't leave your house.

Gardner : : It's a penthouse on Park Avenue. I can't leave because of my disease.

Osteogenesis imperfecta.

Tulsa : Yeah, still don't believe you

Target Text

Tulsa $\quad$ : Benar. Kau tak bisa tinggalkan rumah.

Gardner $\quad$ : Bukan rumah, tapi griya tawang di Park Avenue. Aku tak bisa tinggalkan rumah karena penyakitku, kerapuhan pada tulang

Tulsa : Aku masih tak percaya.

This dialogue through written correspondence voiced, so each other despite being far away, namely Mars and Earth, they can still hear the sound. Talking about the time of the meeting is still a distance apart. Gardner gives understanding if he wants to meet very well but the current conditions do not allow for face to face each other. But Tulsa still does not believe in Gardner who was born on Mars and always hesitated with his communication.

Table 6 Referential error on turn taking: overviewed within translation studies

\begin{tabular}{lll}
\hline \multicolumn{1}{c}{ Source Text (ST) } & \multicolumn{1}{c}{ Target Text (TT) } & Alternative Translation \\
\hline It's a penthouse on Park & $\begin{array}{l}\text { Bukan rumah, tapi griya } \\
\text { tawang di Park Avenue. }\end{array}$ & $\begin{array}{l}\text { Bukan rumah biasa, tapi } \\
\text { Avenue. }\end{array}$ \\
& & Mars di Park Avenue penghuni \\
\hline
\end{tabular}

Based on KBBI (Kamus Besar Bahasa Indonesia), griya tawang is the high-little apartment that lived by some people. Meanwhile, a penthouse means that the special house for living the Mars resident and the TT also gives the description by using "bukan rumah, tapi...", it shows the description translation technique. Alternative translation here is dealing with the understanding and situation there, because the realization of the word a penthouse by translating griya tawang do the ambiguity.

\section{Register Error}

Wilkins (via Pateda., 1989: 40) states “...it is supposed that there are distinct varieties of language associated with people's and these the name register has been given". Mackey (via Pateda, 1989: 40) adds, "Register is a term employed by some linguists to indicate the uses to which a language is put occupational, emotive, and informative". Register error means language variation deals with a job or a work, it indicates the hearer does misunderstanding to mention the meaning of the speaker's work. 
Hereby, the register error is shown in the duration of 25:13-25:18

Source Text

Gardner : Centaur, some privacy!

Centaur : Again? All you ever ask for is privacy these days.

Target Text

Gardner : Centaur, beri aku privasi!

Centaur : : Lagi? Belakangan ini kau sering minta privasi

Centaur is a robot designed to accompany Gardner's activities on Mars. As Gardner scours the profile of his dead mother, he asks the robot to leave it behind because a virtual video show of his parents' video will be turned to find out where he can find his living father. His job now is searching his mother history by using his private computer. But it does not indicate that privacy is privasi itself.

Table 7 Register error on turn taking: overviewed within translation studies

\begin{tabular}{lll}
\hline Source Text (ST) & Target Text (TT) & Alternative Translation \\
\hline some privacy! & beri aku privasi! & Tinggalkan aku sendiri \\
\hline
\end{tabular}

The turn indicates that Gardner wants alone in his activity there. He would like to be flexible without a robot, so he asks to leave me alone (tinggalkan aku sendiri) implicitly. TT to ST uses amplification because ST is more implicit than TT. It changes the form context but it is still in the box of the story.

\section{Society Error}

A human being is us, and we definitely cannot live alone. We need society to interact and communicate each other. In daily conversation, one should focus on social norms and speaker and hearer's life backgrounds such as gender, education, age, habits, social statue-role, etc. Those are someone points to select and use the appropriate words in interacting. The error selects the language, caused by the hearer forgets the social statue of the speaker, affects the social error.

Hereby, the society error is shown in the duration of 1:06:01 - 1:06:50.

Source Text

Shepherd : : You had one job. One job to protect Gardner. To keep him making contact with the outside world. Preventing exactly this kind of eventuality.

Wyndam : You hanging this on me? I admired you more than anyone. We have been shouldering East Texas for you. For years.

Target Text

Shepherd $\quad$ : Tugasmu hanya satu. Melindungi Gardner. Memastikan dia tak berhubungan dengan dunia luar. Mencegah hal terjadinya semacam ini.

Wyndam : Kau menyalahkanku? Aku mengagumimu lebih dari siapapun. Kami membangun Texas Timur untukmu. Selama bertahun - tahun. 
They argue each other to blame each other for knowing the results of the explosion of the plane Gardner was not found by anyone and this makes upset. The sense of tiredness has enveloped them until they walk alone for their own peace of mind.

Table 8 Society error on turn taking: overviewed within translation studies

\begin{tabular}{lll}
\hline Source Text (ST) & Target Text (TT) & Alternative Translation \\
\hline You hanging this on me? & Kau menyalahkanku? & Anda menyalahkan saya? \\
\hline
\end{tabular}

Wyndam feels disappointed when Shepherd gives the weak arguments about her works. It makes her angry when she answers by using a question that indicates the disappointing. But TT applies Kau for you and $A k u$ for me. It is happened the society error, because he is a boss, and she is only the manager. The alternative translation to make it balance in the social statue is Anda for you and Saya for me. TT to ST uses established equivalent in every part of turn taking.

\section{Textual Error}

The textual error is message's misinterpretation implicitly in sentences or discourse. It is the kind of language error that caused by wrong interpretation to sentences or discourse that we hear or read. This error can be caused by the hearer listens unclearly a delivered speech, furthermore, it does the error. Yet, the speaker delivers so many messages to the hearer then makes the hearer forget a few intentions. In writing, the textual error can be caused by unclear text.

Hereby, the textual error is shown in the duration of 58:19-58:27

Source Text

Tulsa : Tell me where are you really from?

Gardner : Mars

Tulsa : You're from Mars?

Gardner : : Ya

Tulsa : Alright. Fine. Don't tell me.

Target Text

Tulsa : : Sebenarnya dari mana asalmu?

Gardner : : Mars

Tulsa $\quad:$ Kau dari Mars!

Gardner $\quad: Y a$

Tulsa $\quad$ Baiklah. Tak usah dijawab.

Gardner and Tulsa met in the school lobby and were shocked and almost could not believe if Gardner came from Mars. The tone of emotion is overwhelmed by Tulsa for being tricked into words that make Gardner silent.

Table 9 Textual error on turn taking: overviewed within translation studies

\begin{tabular}{lll}
\hline Source Text (ST) & Target Text (TT) & Alternative Translation \\
\hline Alright. Fine. Don't tell me. & Baiklah. Tak usah dijawab. & Baiklah. Cukup! \\
\hline
\end{tabular}


Misinterpretation happened when she knows that he comes from Mars. Her disbelief automatically answers by don't tell me that indicates she is nauseated with him, and the translation shows with tak usah dijawab. It adds the errors because the turn situation is disbelief not angry. The alternative translation is enough indication. TT to ST uses transposition technique because changing the active question form into passive question form.

\section{Receptive Error}

The receptive error is the error that caused by the low comprehending or reading skills. It can be categorized such as the hearer pays less attention to speaker's meaning, hearer's situation there is crowded or busy, the delivered speech is unclear, the speakers deliver the ambiguity words and too many meanings' speaker that makes the hearer difficult understand.

Hereby, the receptive error is shown in the duration of 37:30 - 37:46

Source Text

Gardner : Assuming all goes well. I'll be coming to see you.

Tulsa : Cool, and when is this happening?

Gardner : In a few months. There is a longer travelling.

Tulsa : Do not take forever. Once the foster care spits me out, I'm gone.

Target Text

Gardner $\quad$ : Jika semua berjalan lancar, aku akan menemuimu.

Tulsa : Bagus, kapan itu?

Gardner : : Dalam beberapa bulan, banyak yang harus diurus.

Tulsa $\quad$ : Jangan terlalu lama, begitu pengasuhanku berakhir, aku pergi.

Gardner and Tulsa discussed Gardner's health preparations to meet his father. But Tulsa does not quite accept the time given Gardner if a few more months on going to earth due to Tulsa after study at the dormitory will leave the dormitory.

Table 10 Receptive Error on Turn Taking: Overviewed within Translation Studies

\begin{tabular}{llc}
\hline \multicolumn{1}{c}{ Source Text (ST) } & \multicolumn{1}{c}{ Target Text (TT) } & Alternative Translation \\
\hline $\begin{array}{l}\text { Do not take forever. Once } \\
\text { the foster care spits me out, } \\
\text { I'm gone }\end{array}$ & $\begin{array}{l}\text { Jangan terlalu lama, begitu } \\
\text { pengasuhanku berakhir, aku } \\
\text { pergi }\end{array}$ & $\begin{array}{c}\text { Jangan terlalu lama, begitu } \\
\text { pembinaan ini usai, aku pergi }\end{array}$ \\
\hline
\end{tabular}

The foster care is different with taking care because the context indicates that she gets the spiritual founding. It makes the receptive error. The reader will interpret that she is the good or polite girl, actually, she is a bad girl so that she must be in a quarantine. Thus, the TT is questionable. The alternative translation is pembinaan based on the plot story. And the TT to ST uses established equivalence translation technique. 


\section{Expressive Error}

Expressive error related to mistakes made by the speaker. The speakers misrepresent or communicate what they think, feel, and want. The difference of expressive and receptive errors is taken by speech actor components. The receptive error is caused by the hearer, but the expressive error is caused by the speaker.

Hereby, the expressive error is shown in the duration of 1:05:49 - 1:05:58

Source Text

Tom : No bodies!

Wyndam : What? Are you sure?

Tom : Positive. They fellas went to the wreckage. They are alive, somewhere.

Target Text

Tom : $\quad$ Tak ditemukan jasad

Wyndam : Apa? Kau yakin?

Tom : : Pasti. Mereka masih hidup di suatu tempat.

The absolute Tulsa driven airplane crashed into a hut and exploded. But the investigator, Tom, found no one there, at once reporting that Gardner and Tulsa had escaped to somewhere.

Table 11 Expressive error on turn taking: overviewed within translation studies

\begin{tabular}{lll}
\hline Source Text (ST) & Target Text (TT) & Alternative Translation \\
\hline No bodies! & Tak ditemukan jasad & Tak ada siapapun \\
\hline
\end{tabular}

The turn taking from the speaker actually indicates that the wanted person have been died of the accident, but the error from next turn taking is the wanted person is still alive. So it makes the context untrue. The alternative translation is taka ada siapapun that symbolizes the wanted person does not know the position. TT to ST uses transposition translation technique, it changes the construction from phrasal to verb (passive).

\section{Analogical Error}

Alwi., et al (2007: 44) states that generally, people in interaction do the analogical for making the comparison or similarity about something that is discussed between them. It can be character similarity or example comparison. It has the function to make it equivalent either in new language form to another or its strength. The analogical error is an error that is happened when someone has understood the language form learned then he or she applied in another language form.

Hereby, the analogical error is shown in the duration of 33:29 - 34:40

Source Text

Wyndam : How did you get past the electronic lock?

That magnetic implant is there to monitor the growth of your organs. It doesn't serve as a pass key. And how do you even learn how to do that?

Gardner $\quad$ : Raised by scientists in a bubble

Target Text

Wyndam : Bagaimana caramu melewati kunci elektroniknya?

Implan magnetis itu untuk memonitor pertumbuhan organmu. Bukan sebagai kunci pembuka. Dari mana kau pelajari itu?

Gardner $\quad:$ Aku dibesarkan oleh para ilmuwan di dalam sebuah gelembung. 
Wyndam gets angry at Gardner for abusing magnetic implants to unlock the door and get out without permission. However, Gardner still insisted to be able to see his mother's grave. Lucky, saved by Wyndam who followed behind. Afterwards Wyndam gave advice that his mother is now closer to Gardner, which is always in his heart.

Table 12 Analogical error on turn taking: overviewed within translation studies

\begin{tabular}{lll}
\hline Source Text (ST) & \multicolumn{1}{c}{ Target Text (TT) } & Alternative Translation \\
\hline Raised by scientists in a & $\begin{array}{l}\text { Aku dibesarkan oleh para } \\
\text { bubble }\end{array}$ & $\begin{array}{l}\text { Aku dibesarkan oleh para } \\
\text { ilmuwan di dalam sebuah } \\
\text { gelembung. }\end{array}$ \\
\hline
\end{tabular}

The analogical error happened in a bubble, by translating sebuah gelembung make it unclear. The context where he was born in Mars laboratory. To make it clear, it has to apply Mars laboratorium to analogic the situation. TT to ST uses the description because it adds $A k u$ as subject and still in passive construction.

\section{Local Error}

Local error is the error that does not hamper communication. It means that the message is still constant to the speaker meaning and able to be understood by the hearer. Valdman quoted by Ruru and Ruru (via Pateda., 1989: 47), the local error is the linguistics error that affects a form or structure ambiguous, but for the language owner, there is no difficulty in each sentence. The local error can happen when the chosen word only applied in the appropriated area. So, if the words are used to communicate in another area, it makes an error and absolutely unappropriated.

Hereby, local error is shown in the duration of 14:37 - 15:00

Source Text

Nathaniel : The child will never survive the trip back to earth.

John : Yeah but Nathaniel in the eyes of the world. Isn't this whole mission East Texas an experiment? Wouldn't it be forgiven?

Shepherd : Tom, this is not a mouse. This is not a monkey. This is a human being and in the eyes of the world, the lead astronaut with the Genesis Mars mission not only got pregnant but died in child birth

Target Text

Nathaniel : : Anak itu takkan selamat kembali ke Bumi.

John : : Tapi di mata dunia, bukankah misi ini adalah percobaan? Ini bisa dimaafkan

Shepherd : : Percobaan? ini bukan tikus ataupun monyet. Ini adalah manusia. Di mata dunia dunia, pemimpin ini tidak hanya hamil, tapi juga tewas pasca penelitian.

The debate between Nathiel and John in the face of the selfishness of John who wants to give life to a baby who has been born on Mars. This incident arose because the news in mass and electronics media demanding them to take a firm stance. Nathaniel reveals that if the baby is discharged then life will not be long, because of the different gravitational forces between Mars and Earth. While John is very tolerant of the situation and assumes that if this situation is experimental, it is not something to be debated about. But 
the Founder, Shepherd insisted and argued that this was not an experiment but it was a real event that had to be followed up.

Table 13 Local Error on Turn Taking: Overviewed within Translation Studies

\begin{tabular}{lll}
\hline Source Text (ST) & Target Text (TT) & Alternative Translation \\
\hline $\begin{array}{l}\text { will never survive the trip } \\
\text { back }\end{array}$ & takkan selamat kembali & $\begin{array}{l}\text { takkan mampu bertahan } \\
\text { hidup }\end{array}$ \\
\hline
\end{tabular}

Indonesia people prefer to apply "bertahan hidup" than "selamat" in the context of survival, because one who will experience the new situation, it is called by surviving (bertahan hidup). Yet, when one faces the dangerous or threatening situation, she or he is in the part of died or safe (selamat). TT to ST uses adaptation translation technique to change cultural elements in the target text.

Table 14 Local error on turn taking: overviewed within translation studies

\begin{tabular}{lll}
\hline Source Text (ST) & \multicolumn{1}{c}{ Target Text (TT) } & Alternative Translation \\
\hline but died in child birth & $\begin{array}{l}\text { tapi juga tewas pasca } \\
\text { penelitian }\end{array}$ & $\begin{array}{l}\text { tapi juga meninggal usai } \\
\text { melahirkan }\end{array}$ \\
\end{tabular}

There are two words do not represent of Indonesia culture. Died is translated into tewas, it is the lack of understanding because the situation is scientific value. It must be translated into meninggal dunia. Furthermore, childbirth is not absolutely penelitian, even though the condition in the Mars is research and experiment. Simultaneously, consideration the culture and literal meaning must be gathered by the true understanding of word itself. The alternative is melahirkan more representative in every aspects, both in context, word, or value indeed. TT to ST uses adaptation translation technique to change cultural elements in the target text.

\section{Conclusion}

Data findings of language errors on turn-taking happened "The Space between Us" movie are referential, register, society, textual, receptive, expressive, analogical, and local. Data discussions on their effects to translation quality are concentrated by translation techniques on their data findings, they are description, amplification, established equivalence, transposition, and adaptation. Further researcher can develop the language error into the novel, because as a translator, one must know the translation gap in every object.

\section{Acknowledgment}

The researcher highly and gratefully acknowledges the funding support for this study is from Indonesia Endowment Fund for Education (Lembaga Pengelola Dana Pendidikan-LPDP) Scholarship, Ministry of Finance, Republics of Indonesia. 


\section{References}

Baker, Mona. (1992). In Other Words, A Coursebook on Translation. London: Routledge.

Hatim dan Munday. (2004: 6). Translation, An Advanced Resource Book. London: Routledge.

Griffiths, et al. (2006). The Oxford Handbook of Thinking and Reasoning. Oxford: Oxford University Press.

Machali, Rochayah. (2007). Campur Tangan Penerjemah: 'mengkhianati' teks asli? Makalah dalam Seminar Nasional Penerjemahan. FBS UNY.

Markhamad and Sabardila, Atiqa. (2010). Analisis Kesalahan dan Karakteristik Bentuk Pasif. Solo: Jagat Abjad.

Nababan, M., Nuraeni, A., dan Sumardiono. (2012). Model Penilaian Kualitas Terjemahan. Jurnal Kajian Linguistik dan Sastra, 24(1): 39-57. Surakarta: UNS.

Newmark. (1988). A Textbook of Translation. Hertfordshire: Prentice Hall International.

Nida, Eugene A and Charles R. Taber. (1982). The Theory and Practice of Translation. Leiden: E. J. Brill.

Santosa, Riyadi. (2017). Metode Penelitian Kebahasaan. Surakarta: UNS Press.

Thomas, Jenny. (2013). Meaning in Interaction: An Introduction to Pragmatics. London and New York: Routledge Taylor and Francis Group.

Yule, George. (1996). Pragmatics. Oxford: Oxford University Press.

\section{Copyrights}

Copyright for this article is retained by the author(s), with first publication rights granted to the journal.

This is an open-access article distributed under the terms and conditions of the Creative Commons Attribution license (http://creativecommons.org/licenses/by/4.0/). 